\title{
ARANYOSSY Márta
}

\section{SZORZÓSZÁMOS ÉRTÉKELÉS AZ INFORMÁCIÓTECHNOLÓGIAI IPARÁGAKBAN}

Milyen szerepe van a pénzügyi-számviteli fundamentumoknak az információtechnológiai (IT) és internetcégek piaci árazásában? Jelen kutatás egyszerre két oldalról közelíti meg ezt a kérdést: az IT-és internetcégek kulcsértékteremtố tényezôit keresi a piaci árfolyamok tükrében, másrészt a szorzószámos értékelési módszertant igyekszik tesztelni e speciális iparágak mintáján. Az elemzés nyolc cash flow, számviteli és eredményrátán alapuló modellt vet össze többféle becslési hibamutató, statisztikai tesztek és lineáris regresszió segítségével. Az eredmények arra utalnak, hogy míg az IT-cégeknél a leghatékonyabb - EBIT-en és iparági viszonyszámon alapuló - értékelési modellek hasonló hibával becsülnek, mint más iparági modellek a korábbi empirikus vizsgálatok esetében, addig az internetcégek esetében a hibák nagysága már többszörös, így ezen iparágak racionális árazása továbbra is kérdéses.

Kulcsszavak: szorzószámos értékelés, vállalatértékelés, internetcégek

Az információs technológiára (IT) vagy az internet adta lehetôségek kiaknázására specializálódott cégek értéke és értékelése több szempontból is kurrens témája a piaci elemzốknek és kutatóknak. Egyrészt az ezredfordulós „internetlufi” kipukkadása óta a szakemberek különös figyelemmel tekintenek akár a túlélő nagyágyúk, akár a feltörekvő start-up cégek árazására, annak vélt vagy valós gazdasági racionalitására. Másrészt az IT-és internetcégek sajátosságai közé tartozik - mint általában a high-tech, illetve bio-tech cégeknél -, hogy a technológia piacteremtố voltánál és az eszközök intangibilis jellegénél fogva a piaci értékük sokszor minden viszonyítási alapot nélkülöz.

Elsốként tekintsük az ,internetlufi” jelenségét. Az ezredforduló táján az internethez - néhol csak nevükben - kötődő vállalatok árfolyam-emelkedése messze túlszárnyalta a piaci átlagot - ráadásul a pozitív piaci várakozások alapját hiába keresték az elemző́k a vállalatok pénzügyi fundamentumaiban. A befektetốk - utólag úgy túnik - abba a hibába estek, hogy az értékképzés alapját megfoghatatlan, új mérőszámokban vélték felfedezni (pl. weboldalak látogatóinak és lapletöltéseinek száma, 1. Truman et al., 2000), amelyek a valós múködés során legfeljebb gyengén korreláltak a nyereségtermelő képességgel. Természetesen utólag megvizsgálva a pia- ci eufória kialakulását és összeomlását, már inkább azt állapíthatjuk meg, hogy az internet nem változtatta meg a vállalati értékteremtés alapszabályait, és az értékelésnél továbbra is a jövő́beni várható kockázatokat és hozamokat kell mérlegelni (1. Porter, 2001). Ez volt aztán a kiindulópontja a 2000 utáni kutatásoknak is: vajon 2000 márciusa után a befektetốk visszatértek-e a pénzügyi információ alapú árazáshoz? Hand (2001) eredményei szerint ez a kiigazítás többnyire megtörtént, így megszúnt például a veszteség pozitív árazásának anomáliája, és az árak már a profitkilátásokkal együtt emelkedtek csupán. Emellett azonban a jelentôs web-forgalommal rendelkező B2C (business-to-customer) cégeknél az irracionális árazás nyomai megmaradtak - így továbbra is kérdés, hogy a sokkot lassan elfelejtő befektetốk napjainkban nem esnek-e ismét régi hibájukba? Természetesen a jelenlegi gazdasági válság ismét jelentősen lefaragta az IT-vállalatok tôzsdei kapitalizációját, ám az ellenirányú áramlat sem feltétlenül a pénzügyi információkkal korreláló értékítéletet jelent.

Ha azonban maradunk is a hagyományos vállalatértékelés racionalitásánál, még mindig nem könnyú a helyzetünk a high-tech cégek értékelésekor. Egyrészt az információtechnológiával kapcsolatos hozamok és ráfordítások egy része rejtve marad a pénzügyi elemzốk 
szeme elótt (Aranyossy - Nemeslaki, 2005), az értékelés során előtérbe kerülnek az immateriális jószágok, a mérlegen kívüli tételek, a könyv szerinti és az üzleti értéke egyre távolabb kerülhet egymástól (Juhász, 2004). Másrészt ezek az iparágak még viszonylag fiatalok, így historikus pénzügyi adatok nemcsak vállalati szinten, hanem az iparág szintjén is hiányoznak (részben éppen ez volt, ami az elemzóket a rendelkezésre álló nem pénzügyi adatok felhasználására csábította). Harmadrészt az iparág összetételét és a kulcs- technológiákat is a gyors változás jellemzi, így a rendelkezésre álló histori-

kus adatok is kevéssé relevánsak a jövố szempontjából, miközben az előrejelzési bizonytalanság nagy. Így csupán az iparági versenytársak maradnak összehasonlítási alapként - de vajon a hatékony tốkepiacokon a piaci versenytársak friss árazási adatai mennyiben vezetnek a helyes értékeléshez? Amennyiben feltételezzük, hogy a versenytársak árazási információi lehetnek legfóbb támaszaink a vállalatértékelés során, akkor előtérbe kerül a szorzószámos értékelés módszertana.

A fent vázolt értékelési problémák egy részét próbálom megragadni, ritka kivételként az amerikai helyett a számomra helyi, európai tốkepiac(ok)ra koncentrálva, amikor jelen tanulmányomban a következô kérdést teszem fel: Vajon a mai európai tókepiaci befektetôk milyen piaci összehasonlító adatokat és pénzügyi mutatószámokat figyelembe véve árazzák az internet- (és tágabb értelemben az IT-) cégeket? A kérdésfelvetés némileg megfordítva és közvetett módon vizsgálva egyben a szorzószámos értékelési módszer tesztelését is magában foglalja az érintett piacokon, hiszen a kérdés úgy is megfogalmazható: Milyen pénzügyi ráták és milyen benchmark választások adják a legjobb közelítést a valóságban kialakult piaci árfolyamokhoz az IT-, illetve internetcégek esetében?

\section{Elméleti keret: a szorzószámos értékelés lépései}

A szorzószámos értékelés során a vállalatokat hasonló, piac által már beárazott vállalatok pénzügyi mutatószámai segítségével értékeljük (l. például Sebestyén et al., 2004). Ez az egyszerú megfogalmazás négy értékelési lépést takar, ahogy azt az 1 . ábrában olvashatjuk. skálázni $\left(\mathrm{R}_{\mathrm{j}}\right)$

különbségek alapján

értékméröjét
Jelen fejezetben csupán az elsố két lépésre helyezem a hangsúlyt, hiszen nagymintás kvantitatív vizsgálat esetén a vállalatonkénti egyedi szakértői felülvizsgálat

1. ábra

1. megtalálni a hasonló vállalatokat ( $\mathrm{n}$ db vállalat)

$\left.\underset{\mathrm{j}=1}{\mathrm{n}} \underset{\mathrm{R}_{\mathrm{j}}}{\mathrm{k}}\right\}$

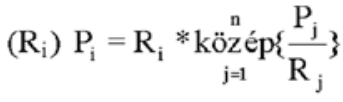

és kiigazítás (3. lépés) megvalósíthatatlan, ráadásul a cél éppen az általános összefüggések felfedése. Mindezek után pedig a hátralevő 4. értékelési lépés már csupán az értékelési képletbe való behelyettesítés.

Vegyük például a sokat használt és vizsgált $\mathrm{P} / \mathrm{E}$ (Price/Earnings, vagyis Részvényár/Egy részvényre jutó nyereség) mutatón alapuló értékelést. Először megkeressük az értékelni kívánt vállalathoz értékteremtési szempontból leghasonlóbb vállalatokat (például az iparági osztályhoz való tartozás alapján), majd kiszámítjuk az ő P/E mutatóikat és valamilyen középértéket (leggyakrabban mediánt) számolunk belőlük. Végül nincs más hátra, mint az, hogy az értékelendő cég egy részvényre esố nyereségét felszorozzuk a kapott benchmark középérték-mutatóval, és így megkapjuk a kívánt részvényárfolyamot. (Többnyire nincs akadálya, hogy egy részvényre esố értékek helyett teljes vállalati értéket használjunk a számlálóban és a nevezóben egyaránt.)

$\mathrm{Az}$ 1. lépés kapcsán a módszer indirekt módon igyekszik beépíteni a fóbb értékteremtô tényezôket is a modellbe, ezeken alapulnak a különbözó gyakorlati megoldások. Például az iparági társak választása arra a feltételezésre épül, hogy ók valószínúleg hasonlóak kockázat és nyereségtermelô képesség szempontjából, illetve hasonló számviteli módszerek torzítják a számviteli adataikat. Az empirikus kutatások e téren elég egységes álláspontot képviselnek: legpontosabb eredményeket a minél pontosabb iparági besorolás alapján érhetjük el (pl. Alford, 1992), így jelen tanulmányban is ezt fogom alkalmazni. Alternatív megoldás lehet emellett valamilyen jövedelmezőségi mutató (pl. ROE, azaz sajáttóke-arányos nyereség, 1. pl. Boatsman - Baskin, 
1981), vagy a méret alapján választani benchmark vállalatot - elôbbit a cash flow termelő képesség, utóbbit a kockázat közelítéseként használva.

A 2. a lépés esetén a megfelelő szorzószám kiválasztását gyakran iparági és egyedi vállalati karakterisztikák is befolyásolják - ehelyütt most csak a témám szempontjából fontos, általános elméleti megfontolásokra térnék ki. Ha az értékelési irodalmat vizsgáljuk általában a szorzószámok három nagy csoportját különböztetik meg (Copeland - Koller - Murrin, 1994): jövedelmezôség alapú (pl. P/E); könyv szerinti érték alapú (Pl. P/BV, azaz Részvényár / Saját tóke könyv szerinti értéke) vagy bevétel alapú mutatók (pl. P/S Részvényár / Nettó árbevétel). Némi átalakítással mindegyik típusú mutató visszavezethetô a - DCF értékelési módszernél is használt - fốbb értékteremtő tényezókre: osztalékkifizetésre, jövedelmezőségre, tốkeköltségre és növekedésre. Az osztalékdiszkont modell alapképletéból lehetôség nyílik mindhárom említett mutatótípus levezetésére, a 2. ábrában látható módon (Damodaran, 2006: p. 62-64.).

Másrészrôl a bevonható mutatószámok - a számítás fenti logikájának változatlansága mellett - a következóképpen is csoportosíthatók (Liu et al., 2002):

- historikus, pénzáramlás jellegú mutatók: cash flow és EBIT, EBITDA alapú mutatók,

- historikus, számviteli mutatók: bevétel, nyereség, saját tốke és eszközök könyv szerinti értéke,

- elôretekintő mutatók: elemzói P/E előrejelzés és $\mathrm{P} / \mathrm{E}$ növekedési (PEG) mutatók.

A cash flow alapú mutatók direkt módon, míg a különböző eredménykategóriákat tartalmazó mutatók indirekt módon utalnak a vállalkozás (jövốbeni) cash flow termelő képességére - így értékelési alkalmazásuk igen gyakori. Még egyértelmúbb a kapcsolat a jövôbeni ér- tékteremtés és az előre jelzett eredmény között, ám az előrejelzések hozzáférhetősége és megbízhatósága kétséges. Fiatal, esetleg egyelőre negatív eredményt kimutató vállalkozások esetében a múltbeli eredmények még kevésbé jó előrejelzók, ilyenkor szokás a bevétel vagy könyv szerinti saját tőke vagy eszközérték használata. A bevétel alapú mutató elméleti megalapozottsága gyenge; ám a P/BV használatának teoretikus alapja Ohlson modellje, mely feltételezi, hogy a saját tốke könyv szerinti értéke azértjóalapajövốbeninormál nyereség elốrejelzéséhez, mivel a vállalat igyekszik az elvárt tókeköltséget megtermelni azon (1. pl. Collins et al., 1999). Jelen tanulmány igyekszik a mutatók mindhárom csoportját bevonni a vizsgálatba,

2. ábra

A szorzószámok és az értékteremtố tényezók kapcsolata

(Damodaran, 2006, p. 62-64.)

Az osztalékdiszkont modell alapja:

$$
\mathrm{P}=\mathrm{DIV} / \mathrm{r}-\mathrm{g}
$$

Ebböl levezetve az említett három típusú mutatót:

$$
\begin{aligned}
& \mathrm{P} / \mathrm{E}=\mathrm{d} *(1+\mathrm{g}) / \mathrm{r}-\mathrm{g} \\
& \mathrm{P} / \mathrm{BV}=\mathrm{ROE} * \mathrm{~d} *(1+\mathrm{g}) / \mathrm{r}-\mathrm{g} \\
& \mathrm{P} / \mathrm{S}=\mathrm{P} * \mathrm{~d} *(1+\mathrm{g}) / \mathrm{r}-\mathrm{g}
\end{aligned}
$$

Ahol P a saját töke piaci értéke, E nyereség, DIV az adott évi osztalék, d az adott évi osztalékfizetési ráta, $\mathrm{g}$ a növekedési ráta, $\mathrm{r}$ a tökeköltség, $\mathrm{BV}$ a saját töke könyv szerinti értéke, ROE a saját töke arányos megtérülési ráta, $\mathrm{S}$ a bevétel és $\mathrm{p}$ a bevételarán yos profitráta.

1. táblázat

Az értékeléshez használt mutatószámok és számításuk módja

\begin{tabular}{|l|l|}
\hline Szorzószám & \multicolumn{1}{|c|}{ Számítás módja } \\
\hline P/FCFE & Tókepiaci kapitalizáció / Tulajdonosok számára rendelkezésre álló pénzáramlás \\
\hline P/FCFF & Tókepiaci kapitalizáció / Vállalat számára rendelkezésre álló pénzáramlás \\
\hline P/EBIT & Tókepiaci kapitalizáció / Kamatok és adózás előtti eredmény \\
\hline P/EBITDA & Tókepiaci kapitalizáció / Kamatok, adózás és értékcsökkenés előtti eredmény \\
\hline P/E & Tókepiaci kapitalizáció / Eredmény \\
\hline P/S & Tókepiaci kapitalizáció / Nettó árbevétel \\
\hline P/BV & Tókepiaci kapitalizáció / Saját tóke könyv szerinti értéke \\
\hline P/TA & Tókepiaci kapitalizáció / Összes eszköz könyv szerinti értéke \\
\hline P/E* & Tókepiaci kapitalizáció / Eredmény * (1 + Előrejelzett éves eredménynövekedési ráta) \\
\hline
\end{tabular}

ám P/E előrejelzések csupán a mintában lévő vállalatok csak egy kisebb csoportjánál állnak rendelkezésre, így ezt a vizsgálatot csak egy ezen az almintán tudjuk elvégezni. A vizsgált szorzószámok körét és számítási módját a 1. táblázat foglalja össze. 
Ritkaság, hogy csak egy benchmark vállalatot választunk ki az értékeléshez (1. Boatsman - Baskin, 1981) - így a következô módszertani döntésre a benchmark vállalati mutatókból számítandó középérték megválasztásakor kerül sor (2. b lépés). A következó bemutatott tanulmányokban gyakorlatilag sehol sem esett a szerzók választása az egyszerú számtani átlagra, ehelyett a következô megállapításokat tették: A medián használata mellett érdemes dönteni, amennyiben szeretnénk a kiugró értékek középértékre gyakorolt hatását csökkenteni (pl. Alford, 1992; Kim - Ritter, 1999; Park - Lee, 2003). Másrészt a szorzószámok hányados volta miatt indokolt lehet a harmonikus átlag használata (Beatty et al., 1999; Liu et al., 2002). Végül a harmonikus átlag - nem egyenlő átlagolandók esetén - mindig kisebb, mint a számtani és a mértani közép, így ezt egyfajta pesszimista benchmark értéknek is tekinthetjük. Jelen tanulmányban a kutatók többségéhez igazodva a benchmark cégek vállalati mutatóinak mediánját fogom használni.

Amint láthatjuk a feltételezésekból és a lépésekbôl egyaránt, a módszer legnagyobb erénye és hátránya egyaránt az egyszerúsége. A legfontosabb kritika így éppen az, hogy ilyen egyszerúen aligha ragadható meg a vállalati értékteremtés teljes spektruma, így, még ha véletlenül helyes értéket eredményez is, akkor sem mond semmit az értékteremtés módjáról, forrásairól. Viszont éppen ez az egyszerúség lehet a vonzó gyakorlati és elméleti célok szempontjából egyaránt. A gyakorlati elemzók számára egy publikus és piaci információkra támaszkodó, egyszerúen frissíthetô eszközt jelent az alul- vagy felülértékelt részvények kiszúrésére. Az állami hatóságok számára is érdekes lehet egy ilyen gyakorlatias értékelési módszer adózási vagy örökösödési esetek elbírálásánál. Emellett a pénzügyi kutatók is használják, hiszen nagymintás vizsgálatokban is megalapozott vállalatértékelés hajtható végre így, például a diverzifikáció vagy a felvásárlások hatását vizsgáló tanulmányoknál. Így tehát önmagában is izgalmas kérdés a szorzószámos értékelési módszer megalapozottságának, illetve pontosságának vizsgálata (ahogy azt a következó fejezetben bemutatott kutatások is példázzák) - jelen tanulmány ezt a kérdésfeltevést egészíti ki az IT-iparág aktualitásaival.

\section{Irodalmi áttekintés: milyen pontos a szorzószámos értékelés?}

A szorzószámos értékelés pontosságának egyik első - és inkább indirekt - vizsgálata Boatsman és Baskin (1981) nevéhez füződik. Ốk ugyan csupán összehasonlításként használtak szorzószámos értékelést, de a módszer tesztelésének tudományos alapjait már náluk is megtalálhatjuk. Ốk az azonos iparági osztályba tar- tozó vállalatok közül véletlenszerúen vagy a megelőző 10 évi átlagos nyereségnövekedési ráta alapján választottak csupán egy benchmark vállalatot az értékeléshez - megállapítva, hogy az utóbbi módszer kisebb értékelési hibát eredményez. Alford (1992) már valóban a szorzószámos értékelésre koncentrált - mégpedig a benchmark választás kérdését vizsgálta meg alaposabban a P/E alapú értékelés esetében. Ebből a tanulmányból származik az azóta is sokat hivatkozott és használt megállapítás, miszerint a legpontosabb értékelési eredményre az vezet, ha viszonylag szúk iparági besorolás alapján választunk benchmark vállalatcsoportot; a méret és a nyereségesség addicionális bevonása a választásba nem javít az eredményeken.

Kaplan és Ruback (1995) ismét inkább összehasonlítási alapként használta az - EBITDA alapú - szorzószámos értékelést nagy tókeáttételú vállalatfelvásárlások értékelése kapcsán. Ám az a következtetés, hogy a diszkontált pénzáramlásokra alapuló módszer „legalább olyan jó", mint a szorzószámos értékelés, már önmagában is sokat elmond a szorzószámos módszer pontosságáról.

Beatty, Riffe és Thompson (1999) tanulmánya számviteli-adózási motivációval keresi a legpontosabb szorzószámos módszert, amit a P/E és P/BV mutatók egyenlố súlyú, harmonikus átlagára alapozott lineáris modellben vélnek megtalálni.

Kim és Ritter (1999) ugyan a tốkepiacra belépó vállalatok, IPO-k esetében a szorzószámos értékelést nem találja meggyőzóen pontosnak sem P/E, sem P/BV, sem P/S mutatókkal; ám módszertani újdonságként az elemzést kiterjeszti az állandó taggal is rendelkező lineáris regressziós egyenletek irányába, illetve a historikus nyereségadatok helyett az előre jelzett nyereségek használata mellett érvelnek. Berkman, Bradbury és Ferguson (2000) szintén P/E elôrejelzéssel dolgozott új-zélandi IPO-k esetében, és a DCF-hez hasonló pontosságot mutatott ki a szorzószámos értékeléssel is.

Liu, Nissim és Thomas 2002-es tanulmánya talán az egyik legalaposabb, valóban pénzügyes nézópontú és csupán a szorzószámos értékelésre fókuszáló vizsgálat: nagy mintával, sokféle szorzószámmal és többféle értékelési modellel dolgozva igyekeztek a legjobbat megtalálni. Ốk is a jövő́beli nyereségen alapuló P/E mutatót találták a legpontosabbnak, majd értékelési hiba tekintetében ezt követik a historikus P/E, a cash flow és a könyv szerinti értéken alapuló szorzószámok, végül a bevétel alapú szorzó bizonyult a legpontatlanabbnak. Jelen tanulmány szempontjából érdekes lehet az a következtetésük, miszerint nem találtak iparáganként „legjobb” mutatót, a fent felvázolt sorrend nagyjából megegyezett minden iparágnál. Az egész módszer ér- 
tékelése szempontjából pedig arra az érdekes következtetésre jutottak, hogy a szorzószámos módszerek mind jobbnak bizonyultak, mint a tesztelt összetettebb, belsô értéken alapuló értékelési módszerek. Vagyis az egyszerúbb ez esetben úgy tûnik, jobb is.

Lie és Lie (2002) tanulmánya hasonlóan alapos és módszertanilag átgondolt. OOk is jobbnak találták az elôre jelzett P/E-t a historikus párjánál, és a legroszszabb a bevétel alapú szorzó volt; azonban a legpontosabb szorzószámnak náluk a P/TA (Részvényár/Összes eszköz) mutatkozott. Érdekes megállapításuk, hogy a nyereség alapú mutatók alapvetóen felfele tévednek, azaz túlértékelik a vállalatokat.

Park és Lee (2003) vizsgálata szerint a legkisebb elôrejelzési hibát a könyv szerinti érték alapú mutató használatával vétjük - ám az ô tanulmányuk még egy érdekes nézőponttal egészíti ki a téma irodalmát: melyik mutató alapján fektessünk be, hogy a legnagyobb piaci hozamot zsebelhessük be? Érdekes módon - bár egy meglehetôsen speciális célfüggvény alapján - itt éppen a bevétel alapú szorzószám bizonyult a leghatékonyabbnak.

A bemutatott tanulmányok diverz nézôpontból és módszertannal igyekeztek tesztelni a szorzószámos értékelés pontosságát, az eredmények alapján talán megfogalmazható mostanra valamilyen általános következtetés: A szorzószámos értékelés többnyire hasonlóan pontos vagy pontosabb, mint a belsố értéken alapuló bonyolultabb (nagy mintán tesztelhetô) módszertanok. Ezen belül a szúk iparági besorolás alapján választott benchmark vállalatok és a $\mathrm{P} / \mathrm{E}$ és/vagy a P/BV mutatók használata a legmegbízhatóbb. Ezt fogom tehát kiindulási alapként használni az IT-és internetes vállalatok szorzószámos értékelési lehetôségeit vizsgálva a továbbiakban.

Az én kérdésfelvetésem azonban kifejezetten azokra a vállalatokra vonatkozik, amelyeket a fenti vizsgálatok többnyire figyelmen kívül hagynak. Egyrészt a high-tech cégek esetében gyakran előfordul, hogy a jövedelmezőség alapú mutatók negatívak, vagy kevés iparági társuk van a tókepiacon - így a fenti vizsgálatok módszertani szempontok alapján kizárták többségüket (pl. Liu et al., 2002 vagy Lie - Lie, 2002). Akad persze néhány olyan tanulmány is, amely kifejezetten ezekre a vállalatokra fókuszál. Rajgopal et al. (2000) kifejezetten az internetes vállalkozásokra koncentrálva azt állapította meg, hogy a számviteli eredmény és a vállalati érték kapcsolata nem szignifikáns. Hasonlóképpen Trueman, Wong és Zhang (2000) is arra a következtetésre jutott, hogy a nyereségességgel nem mutatnak szignifikáns kapcsolatot a részvényárfolyamok, ám az értékesítés közvetlen eredményével már igen. A pénzügyi adatokat pedig hatékonyan egészíthetik ki - leg- alábbis ekkor, az ezredforduló előtti tốkepiacon - a lapletöltésekre vagy látogatószámra vonatkozó statisztikák az értékeléskor. Emellett véleményük szerint leginkább a portál és közösségi oldalak üzemeltetői viselkednek leginkább a hagyományos vállalatoktól eltérően értékelési szempontból. Ahogy azt már a bevezetóben jeleztem, Hand (2001) az internetlufi kipukkadása utáni vizsgálatban is hasonló eredményre jutott azzal, hogy a pénzügyi adatok beárazása ekkor már az internetes cégeknél is jobban hasonlított a piac egészéhez.

Végül az eddig bemutatott tanulmányok szigorúan az amerikai tókepiacokra koncentráltak - jelen tanulmány az európai piacok árazását szeretné vizsgálni. Természetesen az európai internetes cégek árazásának elemzése sem előzmény nélküli. Például Knauff és van der Goot (2001) múhelytanulmánya európai internet IPO-k esetében vizsgálta a számviteli információk és a tôzsdei árak kapcsolatát, és szignifikánsnak találta azt.

\section{A módszertan}

A jelen kutatásban vizsgált fốbb kérdések tehát a következók: Milyen szoros a kapcsolat a pénzügyi fundamentumok és az IT/internetcégek tôkepiaci értéke között Európában? Mennyire pontos a szorzószámos értékelés ezeknél a cégeknél? Mely szorzószámok és mely benchmark választási módszerek a legpontosabbak ezeknél a cégeknél?

Ehhez a kutatáshoz a következóképp szúkítettem a vizsgált vállalatok körét:

- A Bloomberg európai vállalatokra vonatkozó adatbázisának 2008. januári adataiból indultam ki (közvetlen adatforrásom a www.damodaran.com volt). Ez a nyugat-európai tőzsdéken jegyzett cégeket tartalmazza, ezek közül is azokat, amelyeknek a piaci kapitalizációja eléri az ötvenmillió amerikai dollárt.

- Az itt jegyzett cégek közül az információtechnológiához és az internethez szorosan köthető iparági besorolású cégeket választottam ki (a kijelölt iparágak végső, részletes listáját 1. az 1 . mellékletben). Az így kapott 363 vállalatból 280 ITszektorba tartozik, míg 83 az internetszektorba.

- Ezután megtisztítottam az adatbázist a hiányzó értékektől. 28 vállalatnál nem volt cash flowra vonatkozó adat; míg további 6 vállalatnál az árbevétel vagy az eredmény 0 volt, ami a hányadosképzést lehetetlenné tette volna.

- Mind a 8 használt fó szorzószám (l. 3. táblázat) szerint kizártam az 1. és a 100. percentilisbe tartozó vállalatokat, hogy a kiugró értékek kevésbé torzítsák az eredményeket - ez a megközelítés 
egyaránt megfelel a szakmai és a kutatási gyakorlatnak. Így összesen 24 további vállalatot zártam ki outlierként.

- Végül az egyelemú iparágakat is kizártam az elemzésból, mivel e vállalatokhoz nem tudok majd iparági benchmarkot találni. Ezzel négy újabb vállalat esett ki, és így 301 vállalatot tartalmaz a mintám. Ebbőll 60 az internet- és 239 az IT-szektorba tartozik.

A minta alapvető pénzügyi jellemzőit röviden a 2. táblázat foglalja össze - jelezve a mintában szereplő vállalatok rendkívüli diverzitását mind méretben, mind eredményességben.

\section{A minta fóbb jellemzói}

\begin{tabular}{|l|c|c|c|c|c|}
\hline & N & Min. & Max. & Átlag & Szórás \\
\hline Piaci kapitalizáció & 301 & 50 & 60140 & 653 & 3600 \\
\hline Összes eszköz & 301 & 0 & 13494 & 366 & 1261 \\
\hline ROE & 301 & $-100 \%$ & $100 \%$ & $12 \%$ & $26 \%$ \\
\hline
\end{tabular}

A szorzószámos értékelés módszertanáról, lépéseirôl, illetve az általam használt mutatók körérôl már az előző fejezetben esett szó, így ehelyütt csupán az „értékelés értékelésének" módszereit mutatom be - azaz, hogy milyen mutatókkal és tesztekkel vizsgálhatjuk a szorzószámos értékelés pontosságát. Az értékelési hiba leggyakoribb meghatározásai a következók:

- Hiba $=\ln ($ elôre jelzett ár/valós ár) (pl. Kaplan - Ruback, 1995; Kim - Ritter, 1999; Lie - Lie, 2002),

- Hiba = (valós ár - eloore jelzett ár)/valós ár (pl.: Beatty et al., 1999; Liu et al., 2002),

- Hiba = (előrejelzett ár - valós ár)/ valós ár (pl. Alford, 1992; Berkman et al., 2000).

Részemról nem használok logaritmikus transzformációt, mivel szeretném megtartani a hiba alapvetô pénzügyi jelentését. A szakmai megközelítésnek így az utolsó meghatározás felel meg, hiszen ez előjelében is helytálló választ ad arra, hogy az értékelés hány százalékban becsülte alul vagy felül a valódi piaci értéket.

Ezek után kérdés, hogy az egyes vállalatok értékelési hibáit milyen statisztika segítségével összegezzük, vagy milyen tesztek segítségével hasonlítsuk össze. A kutatási gyakorlatban a következő lehetôségek merülnek fel:

\section{2. táblázat} próbával).
- a hiba különböző középértékeinek (átlag, medián, átlagos négyzetes hiba) összehasonlítása,

- a hiba eloszlásának (szórás, interkvartilis terjedelem, 90. percentilis, a hibák hány százaléka esik a +-15\%-ba) összevetése,

- az abszolút hiba középértékeinek (átlag, medián) összehasonlítása,

- a hiba átlagokat összehasonlíthatjuk asszimptotikus z-próba segítségével.

Jelen tanulmányban igyekszem a legtöbb fenti mutató szerint összehasonlítani a különbözó értékelési módokat. (Kivéve az átlagos négyzetes hibát, mivel az előjelek hatásának kiiktatására inkább az abszolút hiba középértékeit használom majd; illetve a hiba 90. percentilise nem mutat túlságosan sokat, több értelme van ezt az abszolút hiba esetében számítani.) Leginkább az abszolút hiba középértékeit és a +-15\%-os intervallumba esók részarányát fogom mértékadónak tekinteni az egyes értékelési módok összevetésénél. A gyakorlatban ugyanis talán e két mutatónak lehet igazán jelentôsége: elóbbinek egy nagyobb portfólió kezelóje számára, míg utóbbinak az egyedi vállalatértékelésekkor. Ezenfeluil a legígéretesebbnek tûnô értékelési módokat a 3. ábrában felvázolt regressziós tesztek és másodfokú sztochasztikus dominancia alapján is összevetem majd.

\section{Az eredmények bemutatása és elemzése}

Amennyiben a vállalatokat szúken értelmezett iparági társaik alapján értékeljük, akkor a 3. táblázatban is látható hatékonyságú modelleket kapunk a nyolc múltbeli pénzügyi adatra épülő szorzószám 3. táblázat fel-

\section{A hasonló empirikus vizsgálatokban is használt statisztikai tesztek}

1. Többek között Kaplan és Ruback (1995) vagy Berkman - Bradbury - Ferguson (2000) is alkalmazza a különbözö vállalatértékelési módszerek összevetésére a lineáris regresszió módszerét, megvizsgálva így, hogy az egyes szorzószámok mennyire magyarázzák a piaci árak varianciáját. $\mathrm{A}$ regressziós egyenlet: $P_{i}=\alpha+\beta * X_{i} *$ Medián $\left(P_{j} / X_{j}\right)$, ahol azt feltételezzük, hogy amennyiben a szorzószámos módszer kellően pontos, akkor $\alpha=0$ és $\beta=1$, ezt teszteljük tehát (F-

2. Emellett Boatsman és Baskin (1981) másodfokú sztochasztikus dominancia alapján hasonlitották össze a különböző értékelési módszerek pontosságát. A másodfokú sztochasztikus dominancia kritériuma esetünkben azt jelenti, hogy ha két különbözö értékelési módszer (abszolút)hiba-eloszlásfüggvénye $F(x)$ és $G(x)$, akkor ha $\int_{-\infty}^{x} F(z) d z \leq \int_{-\infty}^{x} G(z) d z$ igaz minden $\mathrm{x}$-re, úgy a $\mathrm{G}$ modell a domináns. 
használásával. Az elôjeles hibamediánok a P/BV, P/S és P/TA szorzószámok használata esetében nullák, a kapcsolódó szóródási mutatói azonban a bevétel alapú módszernek lényegesen nagyobbak. Az abszolút hiba esetében a P/EBITDA mutató vezet ('így is 50\%-os) mediánhibával és $25,57 \%$-nyi $15 \%$-os hibahatárba eső vállalattal - ám pontosság alapján szorosan követi és szóródás tekintetében meg is előzi ezt a P/BV mutató.

Mivel ez - vagyis az iparági mediánszorzók alapján történő értékelés - a leggyakoribb a szakirodalomban, itt érdemes megállni egy pillanatra és megnézni mélyebben, hogy hogyan teljesítenek a módszerek pusztán az internetcégek almintáján. Itt azt tapasztalhatjuk, hogy a pontos- sági mutatók, több-kevesebb mértékben, minden szorzó esetében romlottak (ld. 4. táblázat). A medián hibák még mindig a P/BV, P/S, P/TA hármasnál a legjobbak, ráadásul a bevétel alapú mutató teljesít egyértelmúen legjobban az abszolút hibák mediánja tekintetében is. Ez azért különösen érdekes, mert a korábbi vizsgálatokban szinte kivétel nélkül a P/S mutató teljesített legrosszabbul, az internetes vállalkozások esetében mégis ez túnik a leghasznosabbnak. Ha viszont a befektetốk bevétel alapon áraznak, annak két oka lehet: egyrészt a negatív eredménymutatók miatt nem találtak jobb viszonyítási alapot, másrészt még mindig nem a pénzügyi racionalitás - azaz az eredménytermelô képesség - alapján döntenek.

3. táblázat

Értékelési hibák iparági medián alapú benchmark választásnál

\begin{tabular}{|c|c|c|c|c|c|c|c|c|}
\hline \multicolumn{9}{|c|}{ Benchmark: iparági mediánok - Hiba } \\
\hline & $\mathrm{P} / \mathrm{FCFE}$ & $\mathrm{P} / \mathrm{FCFF}$ & P/EBIT & P/EBITDA & $\mathrm{P} / \mathrm{E}$ & $\mathrm{P} / \mathrm{BV}$ & $\mathrm{P} / \mathrm{S}$ & P/TA \\
\hline $\mathrm{N}$ & 301 & 301 & 301 & 301 & 301 & 301 & 301 & 301 \\
\hline Átlag & $-0,49$ & $-0,68$ & $-0,39$ & $-0,12$ & $-0,25$ & 0,47 & 0,73 & 0,46 \\
\hline Medián & $-0,47$ & $-0,62$ & $-0,19$ & $-0,08$ & $-0,22$ & 0,00 & 0,00 & 0,00 \\
\hline Szórás & 2,43 & 2,53 & 1,92 & 1,93 & 3,87 & 1,86 & 2,74 & 1,77 \\
\hline Interkvartilis terjedelem & 0,97 & 0,99 & 1,02 & 0,99 & 1,04 & 1,19 & 1,55 & 1,28 \\
\hline \multicolumn{9}{|c|}{ Abszolút hiba } \\
\hline Átlag & 1,21 & 1,21 & 0,90 & 0,89 & 1,19 & 0,97 & 1,22 & 0,95 \\
\hline Medián & 0,77 & 0,84 & 0,53 & 0,50 & 0,52 & 0,57 & 0,59 & 0,62 \\
\hline Szórás & 2,16 & 2,32 & 1,74 & 1,71 & 3,69 & 1,66 & 2,56 & 1,56 \\
\hline 90. percentilis & 2,42 & 2,18 & 1,70 & 1,56 & 2,12 & 1,97 & 2,75 & 1,91 \\
\hline Interkvartilis terjedelem & 0,79 & 0,79 & 0,75 & 0,78 & 0,71 & 0,72 & 0,86 & 0,73 \\
\hline $15 \%$ hibán belüli & $15,74 \%$ & $14,43 \%$ & $21,64 \%$ & $25,57 \%$ & $19,02 \%$ & $19,67 \%$ & $18,36 \%$ & $18,03 \%$ \\
\hline
\end{tabular}

Értékelési hibák iparági medián alapú benchmark választásnál, internetcégek esetében

\begin{tabular}{|l|c|c|c|c|c|c|c|c|c|}
\hline \multicolumn{7}{|c|}{ Csak Benchmark: iparági mediánok internetcégek - Hiba } \\
\hline & P/FCFE & P/FCFF & P/EBIT & P/EBITDA & P/E & P/BV & P/S & P/TA \\
\hline $\mathrm{N}$ & 60 & 60 & 60 & 60 & 60 & 60 & 60 & 60 \\
\hline Átlag & $-1,06$ & $-1,38$ & $-0,99$ & $-0,76$ & $-1,22$ & 0,89 & 1,20 & 0,99 \\
\hline Medián & $-0,68$ & $-0,79$ & $-0,37$ & $-0,30$ & $-0,31$ & 0,00 & 0,00 & 0,00 \\
\hline Szórás & 3,33 & 4,26 & 3,34 & 2,94 & 5,40 & 2,13 & 3,38 & 2,23 \\
\hline Interkvartilis terjedelem & 0,93 & 0,87 & 0,92 & 0,95 & 1,03 & 2,01 & 1,32 & 2,02 \\
\hline & & & Abszolút hiba & & & & \\
\hline Átlag & 1,79 & 2,03 & 1,47 & 1,36 & 1,97 & 1,39 & 1,61 & 1,48 \\
\hline Medián & 0,83 & 0,91 & 0,65 & 0,58 & 0,72 & 0,71 & 0,49 & 0,76 \\
\hline Szórás & 2,99 & 3,98 & 3,15 & 2,71 & 5,17 & 1,84 & 3,20 & 1,94 \\
\hline 90. percentilis & 6,34 & 5,13 & 2,83 & 3,34 & 3,25 & 4,41 & 4,76 & 4,54 \\
\hline Interkvartilis terjedelem & 1,02 & 0,96 & 0,96 & 0,90 & 1,69 & 1,20 & 0,81 & 1,25 \\
\hline $15 \%$ hibán belüli & $10,00 \%$ & $8,33 \%$ & $18,33 \%$ & $21,67 \%$ & $13,33 \%$ & $16,67 \%$ & $25,00 \%$ & $13,33 \%$ \\
\hline
\end{tabular}


Ha a vizsgálatban visszatérünk a vállalatértékelés elméletéhez, akkor talán még az iparági medián benchmark választásnál is jobb eredményt kellene kapnunk, ha a hasonló ROE mutatóval rendelkezô iparági társ mutatói alapján végezzük el a szorzószámos értékelést. Hiszen ekkor elvileg az azonos iparág hasonló kockázatot és növekedési lehetőségeket takar, és a ROE gondoskodik a harmadik értékteremtő tényezô, az eredménytermelő képesség illesztésérôl. Ennek ellenére a mintánkon ez az állítás nem igazolódik - sôt, az értékelési pontosság ezzel a módszerrel szignifikánsan romlik (1. 5. táblázat). A medián abszolút hibák 40-60\%-kal nőnek, míg a 15\%- os hibán belüliek aránya több mint a felére csökken gyakorlatilag az összes szorzószám esetében.

A témában végzett kutatások úgy találták, hogy a nyereség-előrejelzésen alapuló értékelési modellek pontosabbak, mint a múltbeli számviteli adatokat felhasználók (pl. Lie - Lie, 2002; Liu et al., 2002). A százalékos nyereségnövekedési ütemnek természetesen csak a pozitív nyereséget kimutatók almintáján van értelme, jelen mintában pedig azok közül sem áll rendelkezésre mindegyik vállalatnál növekedésre vonatkozó előrejelzés. Így ezt a vizsgálatot egy 96 (89 IT és 7 internetes) vállalatot számláló almintán tudtam csupán elvégezni - és

5. táblázat

Értékelési hibák ROE alapú benchmark választásnál

\begin{tabular}{|c|c|c|c|c|c|c|c|c|}
\hline \multicolumn{9}{|c|}{ Benchmark: iparági leghasonlóbb ROE - Hiba } \\
\hline & $\mathrm{P} / \mathrm{FCFE}$ & $\mathrm{P} / \mathrm{FCFF}$ & $\mathrm{P} / \mathrm{EBIT}$ & P/EBITDA & $\mathrm{P} / \mathrm{E}$ & $\mathrm{P} / \mathrm{BV}$ & $\mathrm{P} / \mathrm{S}$ & $\mathrm{P} / \mathrm{TA}$ \\
\hline $\mathrm{N}$ & 301 & 301 & 301 & 301 & 301 & 301 & 301 & 301 \\
\hline Átlag & $-0,029$ & 0,837 & 1,932 & 1,883 & 2,607 & 1,889 & 4,039 & 2,796 \\
\hline Medián & $-0,548$ & $-0,734$ & $-0,102$ & $-0,093$ & $-0,021$ & $-0,042$ & 0,048 & $-0,042$ \\
\hline Szórás & 13,691 & 20,160 & 9,885 & 13,139 & 11,159 & 7,038 & 18,425 & 14,861 \\
\hline Interkvartilis terjedelem & 1,966 & 2,014 & 1,920 & 1,904 & 2,083 & 1,843 & 2,691 & 2,004 \\
\hline \multicolumn{9}{|c|}{ Abszolút hiba } \\
\hline Átlag & 5,144 & 6,906 & 3,654 & 4,240 & 4,051 & 2,480 & 4,638 & 3,396 \\
\hline Medián & 1,018 & 1,151 & 0,881 & 0,860 & 0,865 & 0,708 & 0,877 & 0,737 \\
\hline Szórás & 12,684 & 18,955 & 9,385 & 12,575 & 10,718 & 6,851 & 18,283 & 14,735 \\
\hline 90. percentilis & 13,103 & 16,132 & 9,495 & 11,349 & 9,822 & 6,003 & 9,108 & 6,140 \\
\hline Interkvartilis terjedelem & 2,607 & 2,613 & 2,033 & 1,692 & 1,521 & 0,837 & 1,538 & 0,969 \\
\hline $15 \%$ hibán belüli & $6,89 \%$ & $5,25 \%$ & $11,15 \%$ & $11,15 \%$ & $8,52 \%$ & $10,16 \%$ & $9,84 \%$ & $8,85 \%$ \\
\hline
\end{tabular}

Értékelési hibák P/E előrejelzésen alapuló értékelés esetében

\begin{tabular}{|l|c|c|c|c|}
\hline \multicolumn{5}{|c|}{ Nyereség-elórejelzésen alapuló P/E modell - Benchmark: iparági medián - Hiba } \\
\hline & P/E előrejelzés & $\begin{array}{c}\text { P/E pozitiv } \\
\text { alminta }\end{array}$ & $\begin{array}{c}\text { P/EBIT pozitív } \\
\text { alminta }\end{array}$ & $\begin{array}{c}\text { P/EBITDA } \\
\text { pozitív alminta }\end{array}$ \\
\hline $\mathrm{N}$ & 96 & 203 & 203 & 203 \\
\hline Átlag & 0,275 & 0,206 & 0,213 & 0,295 \\
\hline Medián & 0,000 & 0,000 & 0,000 & 0,000 \\
\hline Szórás & 1,998 & 1,277 & 1,170 & 2,004 \\
\hline Interkvartilis terjedelem & 0,677 & 0,720 & 0,832 & 0,785 \\
\hline & \multicolumn{4}{|c|}{ Abszolút hiba } \\
\hline Átla & 0,744 & 0,667 & 0,664 & 0,755 \\
\hline Medián & 0,339 & 0,374 & 0,423 & 0,415 \\
\hline Szórás & 1,873 & 1,108 & 0,986 & 1,879 \\
\hline 90. percentilis & 0,925 & 1,249 & 1,289 & 1,487 \\
\hline Interkvartilis terjedelem & 0,701 & 0,722 & 0,710 & 0,733 \\
\hline 15\% hibán belüli & $28,13 \%$ & $26,11 \%$ & $25,12 \%$ & $29,06 \%$ \\
\hline
\end{tabular}

a 6. táblázatban összegzett eredményeket kaptam.

Látható, hogy az előre jelzett P/E-n alapuló értékelés nem pontosabb (de nem is pontatlanabb), mint a múltbeli P/E-n alapuló, vagy a leghatékonyabbnak tûnő EBIT és EBITDA szorzók. Az egyetlen nagyobb mértékú javulás a 90. percentilis értékében következett be, ám mivel ebben az almintában még inkább dominálnak az ITcégek, így az összehasonlítás nem teljes. Viszont éppen ezért meglepó az értékelések elmaradt javulása, ami nem csupán a 
korábbi empirikus eredményeknek mond ellent, hanem jelzi, hogy ebben az iparágban az előrejelzések információtartalma is alulmarad a hagyományos iparágakhoz képest.

\section{Következtetések}

\section{A módszerek statisztikai összevetése}

Jelen fejezetben a statisztikai eszköztár lehetőségeit kiaknázva igyekszem objektíven összevetni a fentiekben bemutatott szorzószámos értékelésimodell változatokat. A korábbiakban már részletesen bemutatottam és elemeztem a hiba középérték és szóródási mutatókat. A gyakorlatban legfontosabb mutatószámokat - azaz a hibaátlagokat és a 15\%-os hibahatáron belüli értékelések arányát - egyszerre tekintve egyaránt a P/EBITDA modell túnik a mintámon legjobbnak - vagyis ezen egyszerú, értékalapú modellel lehet a legtöbb esetben türhetô eredményt kapni. Pontosság tekintetében a második helyen az P/EBIT szorzószám áll, így tehát egyértelmúen a folyamatos múködésból származó jö- vedelem túnik az IT/internetcégek esetében a leghasznosabb értékmérónek.

Ha az abszolút hiba teljes eloszlását figyelembe akarjuk venni a modellek összehasonlításakor, akkor érdemes a legjobbakat a másodfokú sztochasztikus dominancia kritériuma alapján összevetni. Az eredeti nyolc modell között nem találunk egyértelmúen domináns szorzószámot, amely az abszolút hiba bármely szintjét tekintve elfogadhatónak, mindenképp a legtöbb jó eredményt adja. (L. 7. táblázat - ahol az egyes diszkrét hibaszinteken legjobb szorzókat vastag, a legrosszabbakat, dólt betúkkel jelöltem.) Ám a legtöbb esetben - ahogy azt már láthattuk a hibastatisztikákból is - a P/EBITDA szorzószám használata túnik célszerünek, másodsorban pedig a P/E szorzó jöhet még szóba. A klasszikus, eredmény alapú mutatók teljesítenek tehát itt is legjobban, ami megfelel a hagyományos iparágakban tapasztaltaknak. Az pedig egyértelmú és érdekes, hogy a cash flow alapú szorzószámok (P/ FCFE, illetve P/FCFF) adják a legrosszabb közelítéseket, aminek oka részben a negatív cash flow gyakori előfordulása lehet a high-tech cégek esetében.

7. táblázat

Különbözô értékelési szorzószámok összehasonlítása másodfokú sztochasztikus dominancia alapján

\begin{tabular}{|c|c|c|c|c|c|c|c|c|}
\hline \multicolumn{9}{|c|}{$\begin{array}{c}\text { Másodfokú sztochasztikus dominancia } \\
\text { Kummulatív gyakoriság }(\%)\end{array}$} \\
\hline $\begin{array}{c}\text { Abszolút hiba } \\
\%\end{array}$ & P/FCFE & $\mathrm{P} / \mathrm{FCFF}$ & P/EBIT & P/EBITDA & $\mathrm{P} / \mathrm{E}$ & $\mathrm{P} / \mathrm{BV}$ & $\mathrm{P} / \mathrm{S}$ & P/TA \\
\hline $5 \%$ & 8,6378738 & 9,302326 & 8,637874 & 9,96677741 & 12,2924 & 10,96346 & 9,634551 & 10,96346 \\
\hline $10 \%$ & 13,95349 & 12,292359 & 14,61794 & 18,93688 & 15,28239 & 16,6113 & 14,61794 & 13,62126 \\
\hline $15 \%$ & 15,94684 & 14,61794 & 21,92691 & 25,91362 & 19,2691 & 19,93355 & 18,60465 & 18,27243 \\
\hline $20 \%$ & 18,60465 & 17,275748 & 26,24585 & 30,23256 & 23,25581 & 24,25249 & 23,58804 & 21,59468 \\
\hline $25 \%$ & 21,92691 & 20,930233 & 30,89701 & 32,89037 & 30,56478 & 26,9103 & 27,90698 & 26,24585 \\
\hline $30 \%$ & 24,58472 & 24,916944 & 35,8804 & 36,21262 & 35,21595 & 31,56146 & 31,56146 & 28,90365 \\
\hline $35 \%$ & 27,57475 & 26,910299 & 38,53821 & 40,86379 & 38,20598 & 34,88372 & 35,21595 & 31,56146 \\
\hline $40 \%$ & 30,23256 & 27,906977 & 42,52492 & 43,52159 & 40,53156 & 38,87043 & 39,20266 & 34,5515 \\
\hline $45 \%$ & 34,5515 & 29,23588 & 45,84718 & 46,51163 & 46,1794 & 42,52492 & 40,86379 & 38,87043 \\
\hline $50 \%$ & 37,54153 & 30,89701 & 48,50498 & 50,49834 & 49,50166 & 46,51163 & 45,51495 & 42,85714 \\
\hline $55 \%$ & 40,86379 & 34,551495 & 50,83056 & 52,82392 & 51,16279 & 49,83389 & 48,50498 & 46,84385 \\
\hline $60 \%$ & 42,85714 & 37,209302 & 54,15282 & 54,48505 & 53,48837 & 52,15947 & 50,49834 & 49,16944 \\
\hline $65 \%$ & 43,18937 & 41,196013 & 55,48173 & 55,4817276 & 57,1429 & 53,8206 & 53,48837 & 52,82392 \\
\hline $70 \%$ & 45,84718 & 43,853821 & 56,47841 & 57,807309 & 59,1362 & 57,14286 & 55,81395 & 56,47841 \\
\hline $75 \%$ & 48,83721 & 46,179402 & 59,80066 & 61,461794 & 61,4618 & 60,13289 & 57,14286 & 60,13289 \\
\hline $80 \%$ & 50,83056 & 47,508306 & 62,7907 & 63,4551495 & 63,45515 & 62,12625 & 60,13289 & 63,7874 \\
\hline $85 \%$ & 54,48505 & 51,827243 & 66,77741 & 66,7774086 & 66,77741 & 66,44518 & 64,78405 & 66,7774 \\
\hline $90 \%$ & 59,46844 & 56,146179 & 70,76412 & 70,0996678 & 72,093 & 71,7608 & 66,44518 & 70,43189 \\
\hline $95 \%$ & 66,11296 & 60,13289 & 76,07973 & 77,40864 & 76,41196 & 75,74751 & 69,76744 & 74,4186 \\
\hline $100 \%$ & 70,09967 & 68,438538 & 79,40199 & 80,7309 & 79,06977 & 78,73754 & 74,08638 & 78,40532 \\
\hline
\end{tabular}


A fenti vizsgálaton túl érdemes regressziós teszteknek is alávetni a modelleket, hiszen lehetséges, hogy egy modell átlagosan sikeresen közelíti a piaci értéket, ám gyengén teljesít az értékek varianciájának magyarázatakor. A vizsgálat során a 3. ábrában felvázolt regressziós egyenletet használtam, ahol azt feltételezzük, hogy amennyiben a szorzószámos módszer kellően pontos, akkor $\alpha=0$ és $\beta=1$. A 8. táblázat összefoglalja a regressziós vizsgálat során kapott $\mathrm{R}$ és $\mathrm{R}^{2}$ értékeket, illetve az $\alpha$ és a $\beta$ értékre kapott $95 \%$-os konfidencia intervallumokat, (az eddigiek alapján legjobbnak bizonyult három szorzószám esetére).

8. táblázat

A modellek összehasonlítása lineáris regresszió segítségével

\begin{tabular}{|l|r|r|r|}
\hline \multicolumn{4}{|c|}{ Iparági medián, egyváltozós } \\
\hline & P/EBIT & \multicolumn{1}{|c|}{ P/EBITDA } & \multicolumn{1}{c|}{ P/BV } \\
\hline $\mathrm{R}$ & 0,983 & 0,875 & 0,906 \\
\hline $\mathrm{R} 2$ & 0,966 & 0,766 & 0,821 \\
\hline$\alpha$ & 139,560 & 33,457 & $-236,880$ \\
\hline$\alpha$ alsó határ $(\mathrm{p}=95 \%)$ & 62,842 & $-168,083$ & $-416,463$ \\
\hline$\alpha$ felsố határ $(\mathrm{p}=95 \%)$ & 216,278 & 234,996 & $-57,298$ \\
\hline$\beta$ & 0,931 & 0,890 & 1,413 \\
\hline$\beta$ alsó határ $(\mathrm{p}=95 \%)$ & 0,911 & 0,834 & 1,337 \\
\hline$\beta$ felső határ $(\mathrm{p}=95 \%)$ & 0,951 & 0,946 & 1,488 \\
\hline
\end{tabular}

A számított $\mathrm{F}$ értékek alapján a regresszió a piaci értékből minden esetben szignifikánsan nagy hányadot magyaráz meg. Az $\mathrm{R}^{2}$ értékek mindenhol 0,75 felett vannak, és érdekes módon a P/EBITDA modell becslései illeszkednek legkevésbé: még a könyv szerinti értéken alapuló szorzószám is messze jobb, 0,9 feletti
$\mathrm{R}^{2}$-et produkált. Összességében a regressziós P/EBIT modell teljesít legjobban, ám még ennél a modellnél is el kell vetnünk az $\alpha=0$ és $\beta=1$ feltevésünket. A vizsgált modellek esetében ugyanis az $\alpha$ és $\beta$ értékek becsült intervallumaiba nem esik bele a 0 , illetve az 1 (kivéve a P/EBITDA modell alfáját). Azt mondhatjuk tehát, hogy a vizsgált iparági egyváltozós és kétváltozós modellek elég jó becsléseket eredményeznek, de a szorzószámos modell ideális, elméleti formáját - az elemzett európai IT/internet cégek esetében - csak közelítik.

\section{A módszerek a korábbi empirikus vizsgálatok tükrében}

Végül érdemes megvizsgálni, hogy a korábbi empirikus vizsgálatokhoz képest milyen pontosak az eredményeink. Természetesen a különbségek egy része abból eredhet, hogy más időpontban és földrajzilag más piacon figyeltük meg a vállalatok árazását, ám véleményem szerint ez elsősorban a szóródásbeli különbségeket magyarázhatja, a hibanagyságrendek összehasonlítása így is értelmezhetô.

Általánosságban azt állapítottuk meg, hogy míg a leghatékonyabb egyváltozós modellnek az IT/internet cégek esetében a P/EBITDA szorzószám bizonyult, addig a legtöbb vizsgálatban a $\mathrm{P} / \mathrm{E}$ vagy a $\mathrm{P} / \mathrm{BV}$ szorzószámok voltak a legpontosabbak. Âm véleményem szerint ez a fejlemény legalább annyira utalhat az ITcégekbe fektetók racionalitására, mint annak ellenkezőjére, hiszen az EBITDA közvetlenebbül utal a középtávon fenntartható jövedelmezôségre, mint a másik két mutató.

A 9. táblázatból láthatjuk, hogy a P/EBITDA modell átlagos és mediánhibája a teljes mintán nagyjából hasonló a korábbi vizsgálatokban kapott eredményekhez, ám az internetcégek almintáján már lényegesen romló

9. táblázat

Jelen vizsgálat eredményeinek összevetése korábbi empirikus eredményekkel (P/EBITDA)

\begin{tabular}{|c|c|c|c|c|c|c|}
\hline \multicolumn{7}{|c|}{ P/EBITDA - Hiba } \\
\hline & Iparági medián & $\begin{array}{c}\text { Iparági medián } \\
\text { net }\end{array}$ & $\begin{array}{l}\text { Pozitív szorzós } \\
\text { alminta }\end{array}$ & $\begin{array}{c}\text { Kaplan - } \\
\text { Ruback }\end{array}$ & Liu et al. & Lie - Lie \\
\hline Átlag & $-0,116$ & $-0,757$ & 0,295 & $-0,166$ & $-0,111$ & $-0,119$ \\
\hline Medián & $-0,084$ & $-0,301$ & 0,000 & $-0,181$ & 0,000 & $-0,001$ \\
\hline Szórás & 1,929 & 2,944 & 2,004 & 0,254 & 0,676 & \\
\hline Interkvartilis terjedelem & 0,994 & 0,945 & 0,785 & 0,419 & 0,581 & \\
\hline \multicolumn{7}{|c|}{ Abszolút hiba } \\
\hline Átlag & 0,892 & 1,362 & 0,755 & 0,181 & & 0,456 \\
\hline Medián & 0,498 & 0,583 & 0,415 & & & 0,297 \\
\hline $15 \%$ hibán belüli & $25,57 \%$ & $21,67 \%$ & $29,06 \%$ & $37,30 \%$ & & $28,50 \%$ \\
\hline
\end{tabular}


pontosságot tapasztalhatunk. Az abszolút hibák tekintetében még a pozitív szorzószámos alminta sem tudja megközelíteni a hasonló, teljes gazdaságot átfogó vizsgálatok pontosságát, bár a 15\%-os hibán belüli értékelések aránya hasonló.

Az eredményeim a $\mathrm{P} / \mathrm{E}$ szorzó esetében is, csakúgy, mint a P/EBITDA vizsgálata során, leginkább Lie és Lie (2002) hibastatisztikáihoz hasonlítanak (l. 10. táblázat), ami összességében az IT hagyományos iparágakhoz hasonló piaci árazását támasztja alá. Érdekes az is, hogy mindkét eredmény alapú szorzó esetében a teljes mintán és az internetes cégek között is aluláraznak a modellek, ám ha leszúkítjük a vizsgálatot a pozitív eredményú vállalatok körére, ott már felülértékeléssel kell számolnunk, ám a pontosságunk itt legalább megközelíti a korábbi vizsgálatokét. Az internetes cégek esetében azonban a lényegesen nagyobb abszolút és elôjeles hibák már inkább az IPO árazásra hasonlítanak (Kim - Ritter, 1999). Ez részben lehet akár logikus is, hiszen az internetcégek esetében is kevés releváns historikus adat áll rendelkezésre, csakúgy, mint az épp piacra lépó részvényeknél, ám egyben utalhat a meglévő pénzügyi információk nagyobb fokú figyelmen kívül hagyására is. egyelőre nem volt várható, hogy a számviteli mérlegértékek önmagukban nagy magyarázó erôvel bírjanak vállalatérték tekintetében.

\section{Összegzés és kitekintés}

A jelen tanulmányban feltett fơbb kérdésekre tehát a következô válaszokat találtam:

Milyen szoros a kapcsolat a pénzügyi fundamentumok és az IT/internet cégek tókepiaci értéke között Európában? A kapcsolat szoros volta már a korrelációs mátrixból is kiolvasható lehet, hiszen a mintában szereplő vállalatok piaci értéke és az EBIT között 0,974, a piaci érték és a számviteli eredmény között 0,961 a korrelációs együttható. A lineáris regressziós elemzések is azt mutatják, hogy a pénzügyi szorzószámokon alapuló becsült részvényértékek együtt mozognak a piaci értékkel: a legjobb egyváltozós modelleknél az $\mathrm{R}^{2}$ 0,966, és mindegyiknél 0,75 felett van.

Mennyire pontos a szorzószámos értékelés ezeknél a cégeknél? Ha a teljes - európai tôzsdei IT-és internetcég - populációt vizsgáljuk, akkor a legjobb szorzószámos modellek átlagosan 11,6\%-kal becslik alul a piaci árat, míg a vállalatok $25,6 \%$-a esetében vétenek $15 \%$-nál ke-

\section{Jelen vizsgálat eredményeinek összevetése korábbi empirikus eredményekkel}

10. táblázat (P/EBITDE)

\begin{tabular}{|c|c|c|c|c|c|c|c|c|}
\hline \multicolumn{9}{|c|}{ P/E - Hiba } \\
\hline & $\begin{array}{l}\text { iparági } \\
\text { medián }\end{array}$ & $\begin{array}{c}\text { iparági } \\
\text { medián } \\
\text { net }\end{array}$ & $\begin{array}{l}\text { pozitív } \\
\text { szorzós } \\
\text { alminta }\end{array}$ & Alford & $\begin{array}{l}\text { Kim - } \\
\text { Ritter }\end{array}$ & Liu et al. & Lie - Lie & Park - Lee \\
\hline Átlag & $-0,246$ & $-1,218$ & 0,206 & & 0,217 & $-0,046$ & $-0,058$ & \\
\hline Medián & $-0,219$ & $-0,307$ & 0,000 & & 0,328 & 0,000 & 0,002 & \\
\hline Szórás & 3,872 & 5,396 & 1,277 & & & 0,457 & & \\
\hline Interkvartilis terjedelem & 1,041 & 1,033 & 0,720 & & & 0,450 & & \\
\hline \multicolumn{9}{|c|}{ Abszolút hiba } \\
\hline Átlag & 1,192 & 1,967 & 0,667 & & 0,686 & & 0,507 & 0,459 \\
\hline Medián & 0,518 & 0,722 & 0,374 & 0,294 & 0,559 & & 0,342 & \\
\hline 90. Percentilis & 2,116 & 3,250 & 1,249 & 0,725 & & & & \\
\hline $15 \%$ hibán belüli & $19,02 \%$ & $13,33 \%$ & $26,11 \%$ & & $12,10 \%$ & & $25,00 \%$ & \\
\hline
\end{tabular}

Amennyiben a szakirodalomban szintén elterjedt $\mathrm{P} / \mathrm{BV}$ szorzós értékelést is a korábbi empíria tükrében vizsgáljuk, megállapíthatjuk, hogy ez esetben a vizsgált szektorok még inkább eltérnek a gazdaság egészétốl (dupla átlagos elójeles és abszolút hibákkal) és még inkább az IPO értékelésre (Kim - Ritter, 1999) hasonlítanak. Ez természetesen várható volt, hiszen - többek között az immateriális eszközök számviteli kezelésének nehézségei miatt - az IT/internet cégek esetében vesebb hibát a piaci értékhez képest. A mediánhibák 0 és 10\% közé esnek, míg az átlagos abszolút hiba közel $79,7 \%$-os a legjobb esetben is. Ez utóbbi mutatót leszámítva a szorzószámos értékelési módszer tehát ezen iparágban a gyakorlat számára is túrhetố pontossággal múködik, illetve az eredmények nagyjából megegyeznek a más iparágakon végzett empirikus vizsgálatokkal, (ahol az átlagos hiba $-16 \%$ és $+21 \%$ közé; az átlagos abszolút hiba 18\%-68\% közé; a 15\%-nál kisebb hibát 
produkáló cégek aránya pedig 12\%-37\% közé esett). Az abszolút hiba feltúnóen nagy volta a többi statisztika normál intervallumban maradása mellett a kilengések nagy voltára utal. Amennyiben csak az internetcégek almintáját vizsgáljuk, úgy e kilengések még nagyobbak lesznek, és már az átlagos hiba is $-76 \%$ lesz, miközben a $15 \%$-on belüli hibák aránya gyakorlatilag változatlan marad $(25 \%)$. Vagyis az internetcégeket a szorzószámos értékelés nagyon gyakran közel felére árazza csupán a piaci értéknek - ami utalhat a módszer hiányosságaira az értékteremtố tényezốk megragadása terén; ám egyben utalhat a piaci árak pénzügyi valóságtól való ismételt elszakadására is 2007-ben.

Mely szorzószámok és mely benchmark választási módszerek a legpontosabbak ezeknél a cégeknél? A benchmark választás kérdésében az elméletben és gyakorlatban is legtöbbet használt (és egyben talán a legegyszerúbb) módszer hozta a legjobb eredményt: az iparági versenytársak mutatóiból számított medián használata. A leghasonlóbb ROE mutatóval rendelkezó iparági társ hasonló vagy rosszabb hibastatisztikával jellemezhető a mintámon, így hát úgy túnik, a befektetett extra energia és szakértelem nem hozza meg a gyümölcsét pontosság tekintetében. A modell „bonyolítása” csupán az extra változók bevonása terén tûnik kifizetődőnek: a kétváltozós modellekben további pontosítási lehetôség rejlik, amely a késóbbiekben tesztelendő (L. pl. Davis-Friday Gordon, 2005). A kétváltozós modell jelen esetben a P/ EBIT és a P/BV mutatók bevonásával készülhetne, mivel az EBIT kontrollálása mellett a saját tóke könyv szerinti értéke mutatta a legerósebb kapcsolatot a piaci értékkel. A tesztelt szorzószámos modellek közül a legjobbnak - a hiba- statisztikák, a másodrendú sztochasztikus dominancia és lineáris regressziós tesztek után - a P/EBIT és P/EBITDA szorzók tűnnek. Internetcégek esetén néhány iparági specifikumra is bukkanhatunk: miszerint a bevétel alapú szorzó a legjobb mutatók pontosságával vetekedett (vélhetóleg a gyakori negatív eredménymutatók miatt), míg a pozitív tartományban a cash flow alapú mutató (P/FCFF) bizonyult a legjobbnak, miközben a teljes mintán a cash flow szorzók teljesítettek messze a leggyengébben.

Mindezek után visszatérnék még a gondolatébresztố kérdéseim egyikére, miszerint: az IT/internet cégek árazásakor a befektetók más iparágakhoz hasonlóan veszik-e figyelembe a pénzügyi fundamentumokat, illetve nem szakadnak-e el azoktól az irracionális (túl)árazás irányába az ezredfordulóhoz hasonlóan? A kérdés első felére válaszolva azt mondhatjuk, hogy a két szektor részvényárfolyamai alapvetôen hasonló viszonyban vannak a pénzügyi mutatókkal, mint a hagyományos iparágaknál, csupán a nagyobb hibatartományok- ban vannak nagyobb eltérések. Ám az internetcégek almintáján a pénzügyi szorzókra alapuló értékelések már a korábbi vizsgálatokhoz képest sokszoros hibákat produkáltak, így ezen iparágak racionális árazása továbbra is kérdéses. Ráadásul a 2007 óta eltelt hónapokban a gazdasági válság nyomán az IT és internetszektorok részvényárfolyamai drámaian visszaestek, és így további kérdés, hogy vajon ez a visszaesés csupán piaci kiigazítás a pénzügyi valósághoz, vagy egy újabb irracionális árazási hullám, csak éppen az ellenkező irányba. Ezeknek a - pozitív vagy negatív - piaci sokkoknak azonban várhatóan az IT-szektor továbbra is ki lesz téve, éppen azért, mivel múködése sokszor újszerú és immateriális jószág intenzív.

\section{Felhasznált irodalom}

Alford, A.W. (1992): The Effect of the Set of Comparable Firms on the Accurancy of the Price-Earnings Valuation Method; Journal of Accounting Research, Vol. 30, No. 1, p. 94-108.

Aranyossy M. - Nemeslaki A. (2005): Információtechnológiai beruházások megtérülésének modellezése: Problémák és megoldások egy vállalati portál példáján. Vezetéstudomány 9., p. 24-36.

Beatty, R.P. - Riffe, S.M. - Thompson, R. (1999): The Method of Comparables and Tax Court Valuations of Private Firms: An Empirical Investigation; American Accounting Association, Accounting Horizons, Vol. 13, No. 3, p. 177-199.

Berkman, H. - Bradbury, M.E. - Ferguson, J. (2000): The Accuracy of Price-Earnings and Discounted Cash Flow Methods of IPO Equity Valuation; Journal of International Financial Management and Accounting, Vol. 11, No. 2, p. 71-83.

Boatsman, J.R. - Baskin, E.F. (1981): Asset Valuation with Incomplete Markets; The Accounting Review, Vol. 56, No. 1, p. 38-53.

Collins, D.W. - Pincus, M. - Xie, H. (1999): Equity Valuation and Negative Earnings: The Role of Book Value of Equity; The Accounting Review, No. 74, p. 29-61.

Damodaran, A. (2006): Valuation Approaches and Metrics: A Survey of the Theory and Evidence, Working Paper, Stern School of Business, http://pages.stern. nyu.edu/ adamodar/pdfiles/papers/valuesurvey.pdf (2008.07.05.)

Davis-Friday, P.Y. - Gordon, E.A. (2005): Relative Valuation Roles of Equity Value, Net income, and Cash Flow during a Macroeconomic Shock: The Case of Mexico and the 1994 Currency Crisis; Journal of International Accounting Research, Vol. 4, No. 1, p. 1-21.

Hand, J.R. (2001): The Role of Book Income, Web Traffic, and Supply and Deman in the Pricing of U.S. Internet Stocks; European Finance Review, Vol. 5, No. 3, p. 295-317. 
Juhász P. (2004): Az üzleti és könyv szerinti érték eltérésének magyarázata: Vállalatok mérlegen kívüli tételeinek értékelési problémái. Doktori $(\mathrm{PhD})$ értekezés. Budapesti Corvinus Egyetem

Kaplan, S.N. - Ruback, R.S. (1995): The Valuation of Cash Flow Forecasts: An Empirical Analysis; The Journal of Finance, Vol. 50, No. 4, p. 1059-1093.

Kim, M. - Ritter, J. R. (1999): Valuing IPOs; Journal of Financial Economics, Vol. 53, p. 409-437.

Knauff, P. - van der Goot, T. (2001): The Relevance of Reported Financial Information for Valuing European Internet IPOs; Working paper, University of Amsterdam, http://papers.ssrn.com/paper.taf?abstract_id=263176 (2009.04.08.)

Lie, E. - Lie, H.J. (2002): Multiples Used to Estimate Corporate Value; Financial Analysts Journal, March/ April 2002, p. 44-54.

Liu, J. - Nissim, D. - Thomas, J. (2002): Equity Valuation Using Multiples; Journal of Accounting Research, Vol. 40, No. 1, p. $135-172$.
Park, Y.S. - Lee, J. (2003): An Empirical Study on the Relevance of Applying Relative Valuation Models to Investment Strategies in the Japanes Stock Market; Japan and the World Economy, Vol. 15, No. 3, p. 331339.

Porter, M.E. (2001): Strategy and the Internet; Harvard Business Review, March 2001, p. 63-78.

Rajgopal, S. - Kotha, S. - Venkatachalam, M. (2000): The Relevance of Web Traffic for Internet stock prices; Working paper, University of Washington

Sebestyén G. - Fazakas G. - Virág M. - Martin Hajdu Gy. - Pál Á. - Fazakas G. (2004): Vállalati pénzügyi döntések. Tanszék Kft. Budapest

Trueman, B. - Wong, F. - Zhang, X. (2000): The Eyeballs Have It: Searching for the Value in Internet Stocks; Working Paper, http://ssrn.com/abstract $=206648$ (2009.04.08.)

Cikk beérkezett: 2010. 2. hó

Lektori vélemény alapján véglegesítve: 2010. 3. hó

\section{E SZÁMUNK SZERZÖI}

Dr. Farkasné Dr. Kurucz Zsuzsanna, a közgazdaságtudomány kandidátusa, egyetemi docens, Pécsi Tudományegyetem; Lóránd Balázs, egyetemi tanársegéd, Pécsi Tudományegyetem; Balogh Gábor, PhD-hallgató, Pécsi Tudományegyetem; Csepeti Ádám, PhD-hallgató, Budapesti Corvinus Egyetem; Bordáné Rabóczki Mária, tudományos fómunkatárs, Budapesti Corvinus Egyetem, a Hunaudit Könyvvizsgáló Társaság auditigazgatója; Aranyossy Márta, egyetemi tanársegéd, Budapesti Corvinus Egyetem; Czike Anna, PhD-hallgató, Budapesti Corvinus Egyetem 